\title{
The Effect of Solvent on the Crazing of Enameled Wires
}

\author{
by \\ Shigeo MASUDA and Nobuyuki ASANO \\ ( $R \& D$ Group, Sumitomo Electric Ind., Ltd., Shinko-ď̄ri, Minami-ku, Nagoya 457)
}

The effect of solvent on crazing of enameled wires is discussed in the light of rheological data obtained for enameled polymer films. The enamels studied were polyesterimide, modified polyvinyl formal, trimellitic polyamideimide, and Nylon 66. The test wires were specifically prepared by coating these polymers on an oxidized conductor whose adhesion to the polymers was poor, and they were subjected to rheological measurement after treatment by various solvents. Two types of solvent effect were observed on the stress relaxation curves under constant elongation. In one, there was an abrupt change in the stress relaxation rate upon application of the solvent, and in the other, a stress growth for a certain period resulting in a stress relaxation curve with a maximum. This difference seemed to be attributable to the nature of the solvent rather than to the polymer, at least within the tested combinations of polymers and solvents.

The mechanical tan $\delta$ curves of the polymer films stripped from wires were also investigated, with and without application of solvents. It has been found that the shift of the glass transition temperature caused by the solvent is a good measure of the solvent effect on crazing of enameled wires. That is, a solvent which lowers more markedly the glass transition temperature of a given polymer film shows a greater tendency to cause crazing.

\section{エナメル線皮膜のクレージングに及ぼす溶剤の効果}

\author{
增田重雄・浅野信之*
}

(原稿受理：1976年 7 月 7 日)

1. 緒言

エナメル線は導体上に絶縁塗料を燒さ付けて製造される複合材 料である.このエナメル線がコイル巻などの加工を受け皮膜に応 力が残っている状態で, 溶剤による洗浄を受けたり, あるいは含 浸ワニス処理をされると，その溶剤により皮膜にクレージングを 発生することがある. エナメル線の皮膜に発生するクレージング の発生要因の一つは, 皮膜内の残留応力の存在である. そこで筆 者らはエナメル線の製造に执いて導体と皮膜との接着の悪いエナ メル線をつくり, 一定伸長率を与えたあとの皮膜のみの残留応力 を測定し, この残留応力の大きさとクレージング発生程度との関 係を明確にしてきた ${ }^{112)}$.

エナメル線のクレージング発生に打けるもら一つの要因は溶剤 の存在である.ある種の溶剤は応力の存在する皮膜にクレージン

* 住友電気工業(株) 研究開発本部 名古屋市南区新郊通 1 丁目 10 番地
グを発生させるが，ある種の溶剤は全然クレージングを発生させ ないことが知られている。過去ポリマーと溶凪の solubility parameter の関係からポリマーのクレージングを報告した 論文は多 ( (3)4)5). しかし，エナメル線の皮膜には骨格構造を形成する主な 組成物のほかに, 変性剤や架橋剤などが複雑に配合されているた め, エナメル線皮膜の solubility parameter を求めることは困難 である、また，たとえ求まったとしても正確な值を求めることは 難しい.

本実験ではエナメル線を伸長したあと, 溶剤を塗布することに よって現れる皮膜のみの応力緩和举動から, 皮膜と溶剈との相互 作用を実験的に求めるために, 導体と皮膜との接着の悪いエナメ ル線を試料として用いた。 もし導体と皮膜との接着の良いエナメ ル線を用いると, 溶剤を塗布しても皮膜の応力緩和挙動を求める ことができない、な拉，エナメル線から導体を抜き取った円筒状 皮膜を試料して用いた場合には，5\%以下の伸長率で切断する場 
合が多く，あるいは $5 \%$ 以伸長できたとしても溶剤を塗布する と,クレージングはすぐさまクラックへと成長し溶剤の效果を充 分に定量化することができない，

本実験はさらにエナメル線を溶剤中に一定期間浸漬したのち; エナメル線から導体を抜き取った円筒状皮膜の $\tan \delta$ 温度特性曲 線を求め, 浸漬前のエナメル線から導体を抜き取った円筒状皮膜 の $\tan \delta$ 温度特性曲線と比較することにより, 皮膜と溶刘との相 互作用を求めた。本諭文は以上の二つの相互作用をもとに, エナ メル線皮膜のクレージングに及济す溶剛の効果につき検討を加兄 たものである。エナメル線を伸長すると皮膜に応力が残留する。 その後溶剤を塗布すると，クレージングの発生の有無にかかわら ず皮膜の残留応力が緩和する場合と, 增大する場合がある。一方,
一定期間エナメル線を各種の溶剤中に浸漬させると，皮膜の tan $\delta$ 温度特性曲線に変化が起きるものとほとんど起きないものがあ る、クレージングを発生させやすい溶剤と発生させがたい溶剤と によって, 浸漬後の皮膜の $\tan \delta$ 温度特性は相違を示した。

\section{2. 実}

\section{験}

\section{$2 \cdot 1$ 試 料}

本実験に用いたエナメル線の試料を Table 1 亿示す。これらの エナメル線から採取した円筒状皮膜の粘弾性挙動を Fig. 1 亿示 す。な怙，これらのエナメル線は導体を酸化させて導体と皮膜の 接着性が悪くなるように製造した ${ }^{1)}$.

\section{$2 \cdot 2$ 溶 剂}

Table 1. Sample (Bare Wire, $1 \mathrm{~mm}$ Dia.)

\begin{tabular}{clccl}
\hline Enameled Wire & \multicolumn{1}{c}{ Enamel } & $\begin{array}{c}\text { Dielectric Constant } \\
\left(20^{\circ} \mathrm{C}, 1 \mathrm{kHz}\right)\end{array}$ & $\begin{array}{c}\text { Film Thickness } \\
(\mathrm{mm})\end{array}$ & \multicolumn{1}{c}{ Remarks } \\
\hline E I & Polyesterimide & 4.1 & 0.052 & $\begin{array}{l}\text { "Isomide" Schenectady } \\
\text { Chemical Co. }\end{array}$ \\
F & $\begin{array}{l}\text { Polyvinyl formal modified with } \\
\text { phenol formaldehyde resins and } \\
\text { polyisocyanates } \\
\text { Trimellitic polyamideimide }\end{array}$ & 3.6 & 0.051 & Sumitomo Electric Co. \\
A I & Polyamide & 4.4 & 0.051 & Sumitomo Electric Co. \\
N & 3.9 & 0.052 & Nylon 66 Toray Co. \\
\hline
\end{tabular}

Table 2. Solvent

\begin{tabular}{|c|c|c|c|}
\hline Solvent & $\begin{array}{l}\text { Dielectric } \\
\text { Constant* }\end{array}$ & Solvent & $\begin{array}{l}\text { Dielectric } \\
\text { Constant* }\end{array}$ \\
\hline A. Aliphatic hydrocarbons & & F. Esters & \\
\hline Petroleum benzine & 1.80 & Methyl aceto acetate & 17.0 \\
\hline Liquid paraffine & 1.90 & Di- $n$-buthyl phthalate & 6.4 \\
\hline B. Halogenated hydrocarbons & & G. Aromatic hydrocarbons & \\
\hline 1,2-Dichloroethane & 10.4 & Benzene & 2.2 \\
\hline Dichloromethane & 9.1 & Xylene & 2.2 \\
\hline 1,1,1-Trichloroethane & 7.1 & H. Derivetives from Ethylene glycohol & \\
\hline Trichloroethylene & 3.4 & Ethylene glycohol & 38.7 \\
\hline Tetrachloroethylene & 2.3 & Ethylene glycohol & \\
\hline Tetrachloromethane & 2.2 & monoethyl ether & 16.9 \\
\hline C. Alcohols & & Ethylene glycohol & \\
\hline Methyl alcohol & 31.2 & monoethyl ether acetate & 7.5 \\
\hline Ethyl alcohol & 25.7 & I. Organic acides & \\
\hline Isopropyl alcohol & 18.6 & Acetic anhydride & 20.0 \\
\hline$n$-Buthyl alcohol & 17.1 & $m$-Cresol & 11.8 \\
\hline D. Aldehyde & & J. Organic amines and amides & \\
\hline Furfural & 38.0 & N,N-Dimethyl formamide & 16.1 \\
\hline E. Ketones & & Triethanol amine & 29.3 \\
\hline Acetone & 21.4 & K. Water & 78.0 \\
\hline Methyl ethyl ketone & 15.4 & & \\
\hline Diacetone alcohol & 18.2 & & \\
\hline Cyclohexanone & 18.3 & & \\
\hline
\end{tabular}

* Dielectric constant was quoted from "Handbook of Solvents" (1967) edited by the Society of Organic Synthetic Chemistry in Japan. 
本実験に用いた各種溶剤を Table 2 に示す.

\section{$2 \cdot 3$ エナメル線皮膜の溶剤塗布による応力変化}

一定長さ $(20 \mathrm{~cm})$ のエナメル線試料を定速 $(1 \mathrm{~mm} / \mathrm{sec})$ で伸長 すると，エナメル線に付加される応力は増大する (Fig. 2, OA). $t_{1}$ で伸長を停止するとエナメル線の 応力は時間と共化緩和する

(Fig. 2, AB). 次に $t_{2}$ で溶剂を塗布すると，エナメル線皮膜の 残留応力に顕著な変化が起きる，その変化の仕方は大きく分将る と 2 種類となる (Fig. 2, $\mathrm{BC}_{1} \mathrm{D}_{1}, \mathrm{BC}_{2} \mathrm{C}_{3} \mathrm{D}_{2}$ ). 一つは通常の応力緩 和曲線であり, 他の一つは応力增大後応力緩和をしている曲線で ある. $t_{3}$ でエナメル線の皮膜の円周をナイフで切ると皮膜は収縮 する。そ結果，溶剤塗布後の皮膜の残留応力が求まる (Fig. 2, $\left.\mathrm{D}_{1} \mathrm{E}, \mathrm{D}_{2} \mathrm{E}\right)$. EG は導体の残留応力である。な扔，本実験に打い てェナメル線执よび溶剤の温度は $20 \pm 1{ }^{\circ} \mathrm{C}$ に保った。 ここで, $\left(t_{1}-t_{0}\right)=10 \mathrm{sec},\left(t_{2}-t_{1}\right)=60 \mathrm{sec},\left(t_{3}-t_{2}\right)=60 \mathrm{sec}$ とした。な お，本実験には島津製作所製の「オートグラフ S-100」を用いた。

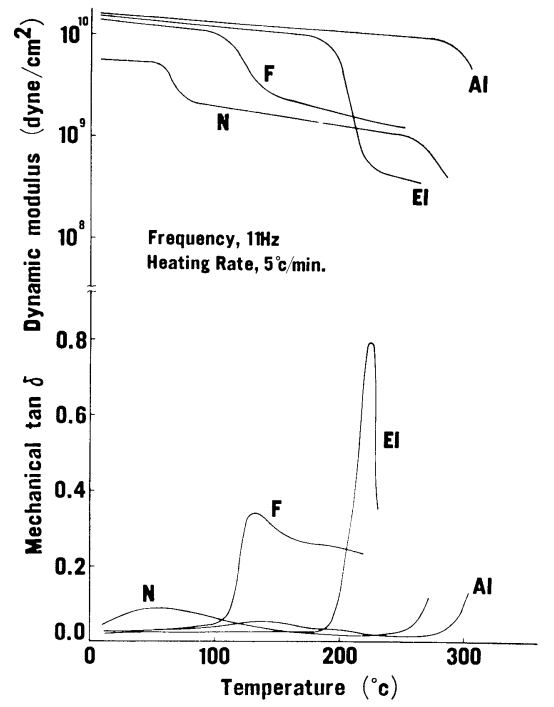

Fig. 1. Viscoelastic behavior of samples (Frequency $11 \mathrm{~Hz}$. Heating Rate $5^{\circ} \mathrm{C} / \mathrm{min}$.)

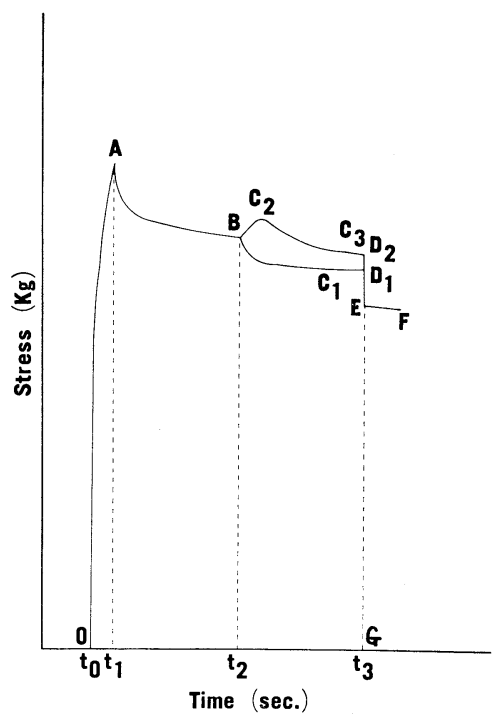

Fig. 2. Two typical stress relaxation curves due to solvent.

\section{$2 \cdot 3 \cdot 1$ 応力緩和を示す場合の皮膜の応力緩和量の求め方}

溶剂を塗布した時, 皮膜の残留応力が緩和する場合の応力緩和 量の求め方を Fig. 3 飞示す。応力緩和曲線 $\mathrm{BC}_{1} \mathrm{D}_{1}$ に打ける $\mathrm{D}_{1}$ 点での接線と， $\mathrm{BI}$ との交点を $\mathrm{H}$ とすると， $\mathrm{BH}$ を溶剤塗布に帰因 する緩和量とした。

\section{$2 \cdot 3 \cdot 2$ 応力増大後応力緩和を示す場合の皮膜の 応力緩和量 の求め方}

溶剂を塗布した時，皮膜の残留応力が增大し，その後応力緩和 をする場合の応力緩和量の求め方を Fig. 4 亿示す。ここで溶剤 塗布によって生じる応力の極大值を $\mathrm{C}_{2}$ とする。 $\mathrm{C}_{2}$ から横軸へ下 した垂線と応力緩和曲線 $\mathrm{BC}_{2} \mathrm{C}_{2} \mathrm{D}_{2}$ に打ける $\mathrm{D}_{2}$ 点での接線との 交点を $\mathrm{J}$ として， $\mathrm{C}_{2} \mathrm{~J}$ を溶剤塗布に帰因する応力緩和量とした。

\section{$2 \cdot 4 \tan \delta$ の測定}

一定温度 $\left(20^{\circ} \mathrm{C}\right)$ に保持した各種溶剤にエナメル線を 168 時間

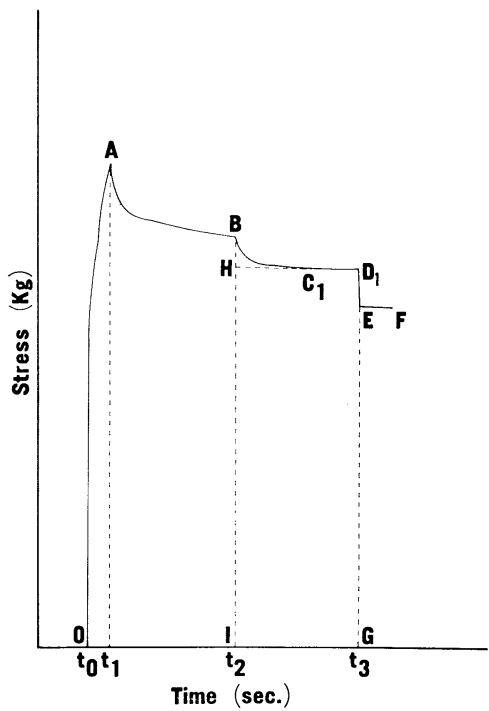

Fig. 3. Quantitative method to obtain the amount of stress relaxation in the stress relaxation curve.

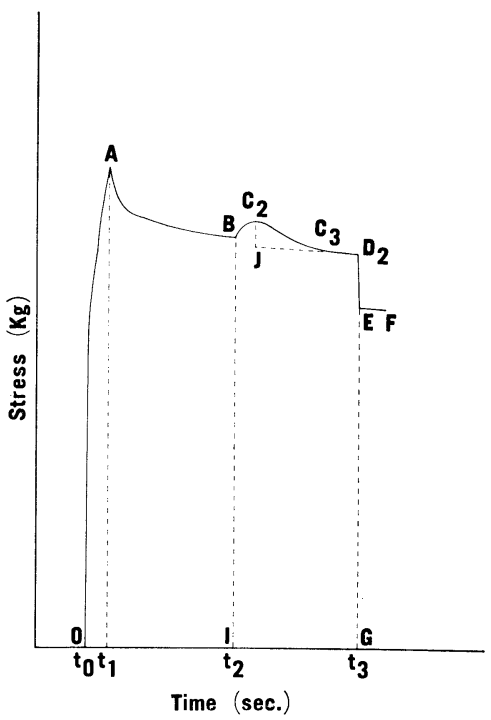

Fig. 4. Quantitative method to obtain the amount of stress relaxation in the stress relaxation curve after stress increased. 
Table 3. Stress relaxation curves obtained by applying solvents on the enameled wires.

1, Stress Relaxation after stress increased

2, Stress Relaxation

(Sufix "C" indicates that craze was observed on the film. Crazing was checked by the microscope. $(\times 40))$

\begin{tabular}{|c|c|c|c|c|}
\hline Solvent & EI & $\mathrm{F}$ & AI & $\mathrm{N}$ \\
\hline Petroleum benzine & 1 & 1 & 1 & 1 \\
\hline Liquid paraffin & 2 & 2 & 2 & 2 \\
\hline 1,2-Dichloromethane & $1-\mathrm{C}$ & $1-\mathrm{C}$ & 1 & 1 \\
\hline Dichloromethane & $1-\mathrm{C}$ & $1-\mathrm{C}$ & 1 & 1 \\
\hline 1,1,1-Trichloroethane & $1-\mathrm{C}$ & $1-\mathrm{C}$ & 1 & 1 \\
\hline Trichloroethylene & $2-\mathrm{C}$ & $1-\mathrm{C}$ & 1 & 1 \\
\hline Tetrachloroethylene & $2-\mathrm{C}$ & 1 & 1 & 1 \\
\hline Tetrachloromethane & 1 & 1 & 1 & 1 \\
\hline Methyl alcohol & $1-\mathrm{C}$ & $1-\mathrm{C}$ & $1-\mathrm{C}$ & 1 \\
\hline Ethyl alcohol & $1-\mathrm{C}$ & $1-\mathrm{C}$ & $1-\mathrm{C}$ & 1 \\
\hline Isopropyl alcohol & $1-\mathrm{C}$ & $1-\mathrm{C}$ & 1 & 1 \\
\hline$n$-Buthyl alcohol & $2-\mathrm{C}$ & $2-\mathrm{C}$ & $2-\mathrm{C}$ & 2 \\
\hline Furfural & $2-\mathrm{C}$ & $2-\mathrm{C}$ & $2-\mathrm{C}$ & 2 \\
\hline Acetone & $1-\mathrm{C}$ & $1-\mathrm{C}$ & $1-\mathrm{C}$ & 1 \\
\hline Methyl ethyl ketone & $1-\mathrm{C}$ & $1-\mathrm{C}$ & $1-\mathrm{C}$ & 1 \\
\hline Diacetone alcohol & $2-\mathrm{C}$ & $2-\mathrm{C}$ & 2 & 2 \\
\hline Cyclohexanone & $2-\mathrm{C}$ & $2-\mathrm{C}$ & 2 & 2 \\
\hline Methyl acetoacetate & $2-\mathrm{C}$ & $2-\mathrm{C}$ & $1-\mathrm{C}$ & 1 \\
\hline Di-n-buthyl phthalate & 2 & 2 & 2 & 2 \\
\hline Benzene & $1-\mathrm{C}$ & $1-\mathrm{C}$ & 1 & 1 \\
\hline Xylene & $2-\mathrm{C}$ & $2-\mathrm{C}$ & 1 & 1 \\
\hline Ethylene glycohol & $2-\mathrm{C}$ & $2-\mathrm{C}$ & $2-\mathrm{C}$ & 2 \\
\hline $\begin{array}{l}\text { Ethylene glycohol } \\
\text { monoethyl ether }\end{array}$ & $2-\mathrm{C}$ & $2-\mathrm{C}$ & $2-\mathrm{C}$ & 2 \\
\hline $\begin{array}{l}\text { Ethylene glycohol } \\
\text { monoethyl ether acetate }\end{array}$ & $2-\mathrm{C}$ & $2-\mathrm{C}$ & $2-\mathrm{C}$ & 2 \\
\hline Acetic anhydride & $2-\mathrm{C}$ & $2-\mathrm{C}$ & 2 & 2 \\
\hline$m$-Cresol & 2 & 2 & 2 & 2 \\
\hline $\mathrm{N}, \mathrm{N}$-dimethyl formamide & $2-\mathrm{C}$ & $2-\mathrm{C}$ & $2-\mathrm{C}$ & 2 \\
\hline Triethanol amine & 2 & 2 & 2 & 2 \\
\hline Water & 1 & 1 & 1 & 1 \\
\hline
\end{tabular}

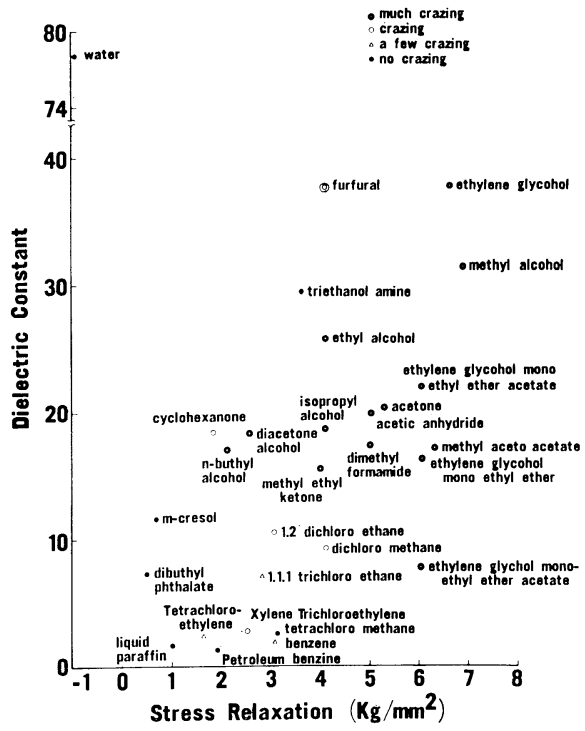

Fig. 5. Relation between the dielectric constant of solvent and stress relaxation of Polyesterimide (EI) film.
浸漬し，エナメル線皮膜に溶剤を浸透させた。そのあとエナメル 線を取り出し，導体を抜き取って皮膜の $\tan \delta$ 温度特性を求めた。 エナメル線を溶剤から取り出し測定を開始するまでの時間は 5 分 以内とした。な拈， $\tan \delta$ の測定は東洋ボールドウイン社製の Rheovibron DDV-II-B を用いた。試料長さは $10 \mathrm{~mm}$ ，周波数は $11 \mathrm{~Hz}$ ，年温速度は $5^{\circ} \mathrm{C} / \mathrm{min}$ とした。

\section{3. 結果}

\section{$3 \cdot 1$ 溶剤塗布による皮膜の応力緩和曲線の種類}

Fig. 2 に示すよ5に, 本実験の方法では溶剤塗布によって二 つの代表的応力緩和曲線が得られた。 いずれの曲線に招いてもク レージングを発生する場合と発生しない場合が存在した.Table 3 にエナメル線と溶剤の組合せに㧍ける応力緩和曲線の種類とクレ

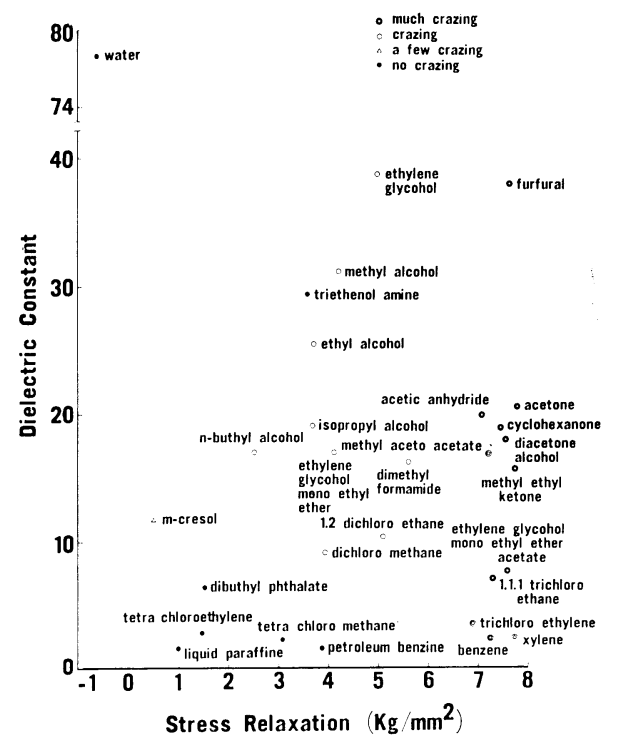

Fig. 6. Relation between the dielectric constant of solvent and stress relaxation of Polyvinylformal (F) film.

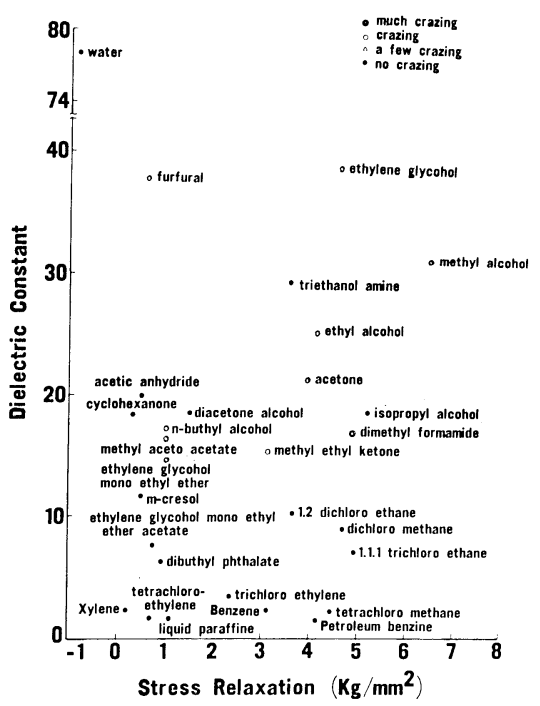

Fig. 7. Relation between the dielectric constant of solvent and stress relaxation of Polyamideimide (AI) film. 


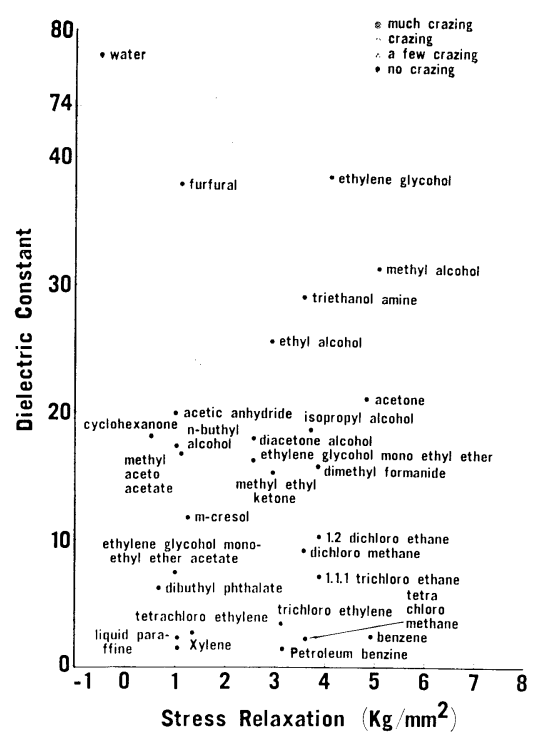

Fig. 8. Relation between the dielectric constant of solvent and stress relaxation of Polyamide (N) film.

\section{ージング登生の有無を示す。}

\section{3 ・2 溶剤の誘電定数と溶剂塗布による皮膜の応力緩和量の関 係}

本実験で用いた各種溶剤の誘電定数と, 項 $\mathbf{2} \cdot \mathbf{3}$ で述べた方法 から求めた皮膜の応力緩和量との関係を Fig. 5 8 亿示す.

\section{4. 考察}

\section{$4 \cdot 1$ 応力緩和曲線}

本実験に和いて最も興味ある事実は, 伸長したエナメル線に溶 㑉を塗布すると, 皮膜の残留応力が緩和する場合と増大する場合 が存在することである．これらの曲線は応力状態下でのエナメル 線の皮膜と溶剤との間の力学的相互作用関する情報を与えてく れる．筆者らはこのように応力が残留している状態に淤ける皮膜 と溶剛との相互作用を Dynamic Solubility と呼びたい。そして 通常の応力緩和を示す場合をPositive Dynamic Solubility と呼び, 応力增大後応力緩和を示す場合を Negative Dynamic Solubility と呼んで区別したい.

さて，応力緩和曲線の場合は，(1)溶剂によって高分子鎖が流動 する，(2)溶剤によってクレージングが発生する，といら二つが要 因として考えられる，一方，溶剤塗布によって応力が増大しその 後緩和する場合は，溶剤によって高分子鎖が収縮する結界と考兄 られる。しかしながら，伸長した皮膜内の残留応力が溶剤塗布に よって増大する場合にもクレージングが発生する場合があるとい らことは, 本実験のような応力緩和曲線の形だけからクレージン グの発生を予測できないことを示している.

溶剤塗布によって生じる応力緩和曲線は大きく分けると二種類 であるが，さらに応力緩和曲線を詳細にみると，応力緩和を示す 曲線に扔いては応力緩和した応力が增大する場合がある (Fig. 9)。 このような曲線を示すのは溶剤塗布によって皮膜の残留応力が急 激に緩和する場合に現れる。この現象はクレージング発生の有無 にかかわらず生じるもので，ポりマーの变形履歴の記憶現象に由 来するものと推定される.

本実験に扣いて第二番目に興味ある現象は，この二種類の応力

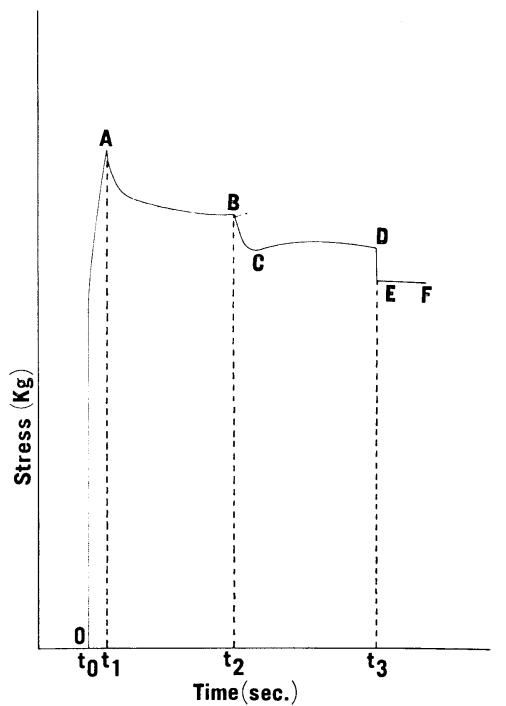

Fig. 9. Stress increasing after stress relaxation indicating the memory phenomenon of polymer.

緩和曲線は，本実験で用いたエナメル線の皮膜の種類の範囲内で は, それらの化学構造とは無関係に塗布する溶剤に左右されてい るという事実である (Table 3). 本実験に用いたエナメル線の皮 膜の化学構造は非常に異なったものであるが，溶剤が同一である とほぼ同様の応力緩和曲線を示している。 しかし, クレージング 発生の有無扣よび応力緩和量の大小はエナメル線の皮膜と溶剤の 個々の組み合わせによって異なっている.

\section{$4 \cdot 2$ 溶剤の誘電定数と皮膜の応力緩和量}

エナメル線の皮膜の誘電率は大体 3 〜 でほぼ同程度の值を示 しているのに対し，各種溶剤の誘電率は大きく異なっている。一

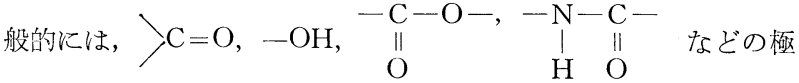
性基をもった溶剤は大きな誘電定数をもち応力緩和を起こしやす い.エナメル線の皮膜の種類によって若干異なるが, 応力緩和量と 溶剤の誘電定数との間には高い相関関係がある．Fig. 5〜8 は皮 膜の応力緩和量と共にクレージング発生の程度を同時に表してい る. Fig. 5 亿示すポリエステルイミド線を除くと, クレージング の発生程度と溶剤の誘電定数との関係は皮膜の応力緩和量と溶剈 の誘電定数との関係汪ど明確ではない．Fig. 8亿示すように代表 的な直鎖状ポリマーの Nylon 66 を塗布焼き付けした Nylon 66 線は肉眼打よび光学顕微鏡（×40）で確認できるクレージングは 発生していない，一方，代表的な熱硬化性のポリエステルイミド 線に扣いては, クレージングの発生程度と溶剤の誘電定数との間 にかなり良い相関性が存在する。

\section{$4 \cdot 3$ 溶剂浸漬後の皮膜の $\tan \delta$ 温度特性}

エナメル線の皮膜と溶剤の相互作用を検討するために，エナメ ル線を一定期間溶剤の中に浸漬し，溶剤が浸透した皮膜の $\tan \delta$ 温度特性と, 溶剤に浸漬する前のいわゆる溶剤を含まない皮膜の $\tan \delta$ 温度特性を比較した。 クレージングを発生させやすい溶剤 の場合，その溶剤の中へエナメル線を一定期間浸漬した後の皮膜 のガラス転移温度は, $\tan \delta$ 温度特性から判断して大きく低下し ている，一方，エナメル線を伸長した後溶剤を塗布した将，皮膜 の残留応力の緩和量は大きいがクレージングを発生しがたい溶剤 
の場合は，その溶剤の中へエナメル線を一定期間浸漬しても， $\tan \delta$ 温度特性から判断してガラス転移温度はあまり低下してい ない，皮膜と溶剤との相互作用を議論するにさいし， $\tan \delta$ 温度 特性を求める測定に执いて, 年温過程で浸透した溶剤が皮膜から 蒸発していく，そのために溶剤の沸点の差が溶剂浸漬後の皮膜の $\tan \delta$ 温度特性に影響を及ぼすことが考えられ， $\tan \delta$ 温度特性 からエナメル線皮膜と溶剤の関係を定量的に議論することに問題 を残している. しかし，本実験で用いた溶倣では，沸点の高低に かかわらずクレージングを発生させやすい溶剤は, 皮膜のミクロ ブラウン運動をより低温から起こさせる傾向をもっていることが, 皮膜の $\tan \delta$ 温度特性から明らかとなった。代表的な例としてポ リアミドイミド皮膜に対するエチレングリコールとジメチルフォ ルムアミドを比較する。ポリアミドイミド皮膜に刘しでチレン グリコールは，クレージングをわずかに発生させるだけであるの に刘し、ジメチルフォルムアミドはクレージングを非常によく発 生させる. Fig. 10 は伸長したポリアミドイミド線に対してェチ レングリコールおよびジメチルフォルムアミドを塗布した時の応

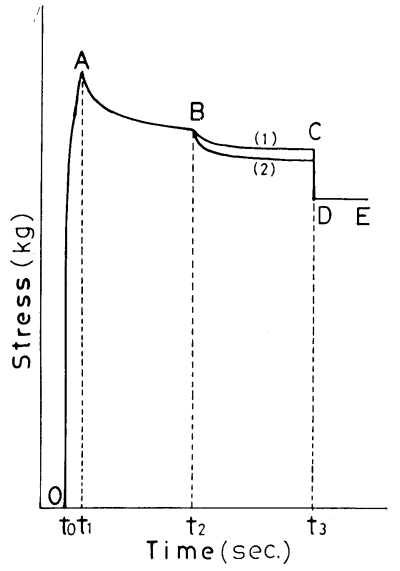

Fig. 10. Stress relaxation of Polyamideimide due to Ethylene glycohol (1) and Dimethyl formamide (2).
力緩和曲線である. Fig. 11はポリアミドイミド線を $25^{\circ} \mathrm{C} て ゙ 168$ 時 間それぞれの溶剤中に浸漬した後の皮膜の $\tan \delta$ 温度特性を表し ている. Fig. 11 から分かるようにジメチルフォルムアミドは， ポリアミドイミド皮膜を膨潤させる力が強い。一力，エチレング リコールはポリアミドイミド皮膜を膨潤させる力は弱い，このよ 弓に一定条件のもとにェナメル線を溶剤中に浸漬し, その後の皮 膜の $\tan \delta$ 温度特性と浸漬前の皮膜の $\tan \delta$ 温度特性の差は, エナメル線の皮膜と溶剤との間の一つの 相互作用の 結果である と解釈することがでさる，筆者らはこの相互作用を先に述べた Dynamic Solubility に刘応させて Static Solubility と呼んで区別 したい。この Static Solubilityを定量化する一つの方法として, 例えば溶剤浸漬前後の $\tan \delta$ 温度特性曲線に打いて, ミクロブラ ウン運動を起こし, $\tan \delta$ の值が 0.1 を示す温度を $T_{g i}, T_{g f}$ と 乙 $\Delta T_{g}\left(=T_{g i}-T_{g f}\right)$ を求めるならば, $\Delta T_{g}$ は Static Solubility を示すパラメータとなりらる. Table 4 に各種エナメル線と代表 的溶剤の組み合わせから求めた $\Delta T_{g}$ を示す. ここで改めてクレ ージングの発生程度と $\Delta T_{g}$ を比較検討すると, クレージングを

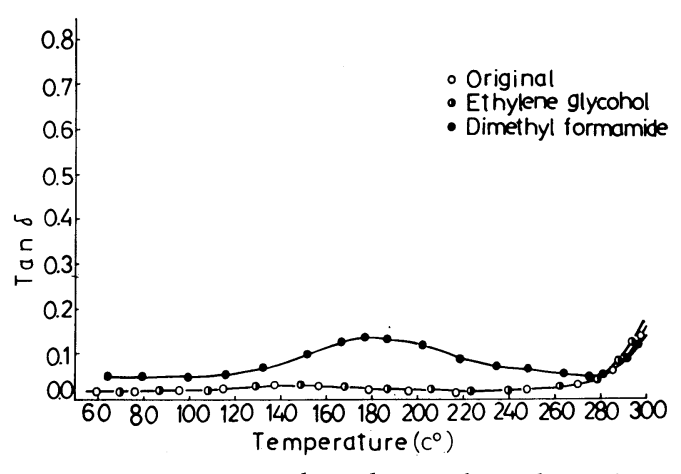

Fig. 11. Temperature depandence of mechanical tan $\delta$ of Polyamideimide after immersion in Ethylene glycohol and Dimethyl formamide (Immersion period, 10 days; Solvent temperature, $20^{\circ} \mathrm{C}$; Frequency, $11 \mathrm{~Hz}$; Heating rate, $5^{\circ} \mathrm{C} / \mathrm{min}$.)

Table 4. $\Delta T_{g}$ (a parameter of static solubility) obtained from the mechanical $\tan \delta$ vs. temperature plots

\begin{tabular}{|c|c|c|c|c|}
\hline Solvent & $\begin{array}{c}\mathrm{EI}\left(T_{g i}=192^{\circ} \mathrm{C}\right) \\
\Delta T_{g}\end{array}$ & $\begin{array}{c}\mathrm{F}\left(T_{g i}=116^{\circ} \mathrm{C}\right) \\
\Delta T_{g}\end{array}$ & $\begin{array}{c}\mathrm{AI}\left(T_{g i}=288^{\circ} \mathrm{C}\right) \\
\Delta T_{g}\end{array}$ & $\begin{array}{c}\mathrm{N}\left(T_{g_{i}}=60^{\circ} \mathrm{C}\right) \\
\Delta T_{g}\end{array}$ \\
\hline Liquid paraffine & 5 & 1 & 2 & 1 \\
\hline 1,1,1-Trichloroethane & 3 & 1 & 1 & 1 \\
\hline Furfural & 38 & 90 & 9 & 1 \\
\hline Methyl ethyl ketone & 17 & 69 & 1 & 1 \\
\hline Di-n-buthyl phthalate & 1 & 1 & 1 & 1 \\
\hline Xylene & 12 & 1 & 1 & 1 \\
\hline Ethylene glycohol & 10 & 3 & 5 & 1 \\
\hline$m$-Cresol & 7 & 30 & 2 & 1 \\
\hline $\mathrm{N}, \mathrm{N}$-dimethyl formamide & 67 & 82 & 144 & 1 \\
\hline Triethanol amine & 1 & 1 & 1 & 1 \\
\hline Water & 1 & 1 & 1 & 1 \\
\hline
\end{tabular}

1) Specimens were immersed into the solvents for $168 \mathrm{hrs}$. at $20^{\circ} \mathrm{C}$. Tan $\delta$ measurement was started at $5 \mathrm{~min}$. after it was taken out of the solvent.

2) Apparatus, Rheovibron DDV-II-B manufactured by Toyo-Baldwin Co.; frequency, $11 \mathrm{~Hz}$; heating rate, $5^{\circ} \mathrm{C} / \mathrm{min}$.; length of tubed film, $10 \mathrm{~mm}$. 


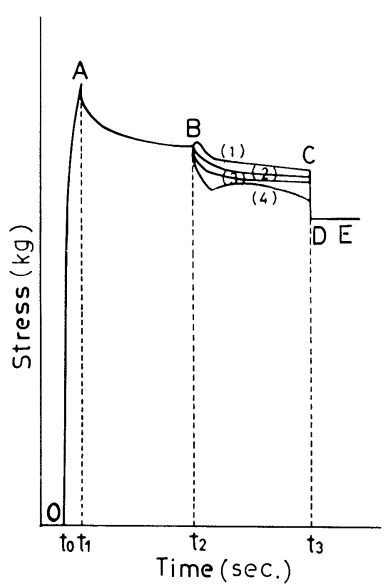

Fig. 12. Stress relaxation curves of Polyesterimide (EI) at various temperatures of Dimethyl formamide (1) $10^{\circ} \mathrm{C},(2) 20^{\circ} \mathrm{C},(3) 30^{\circ} \mathrm{C},(4) 40^{\circ} \mathrm{C}$.

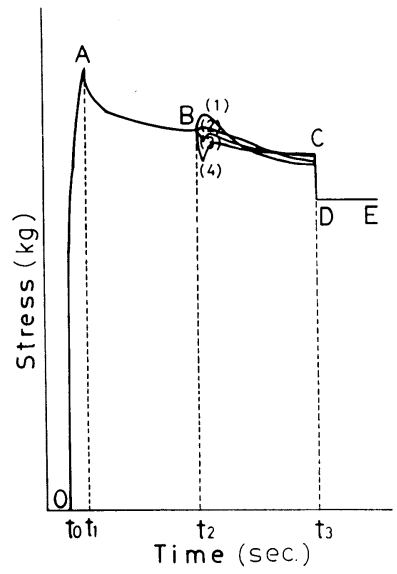

Fig. 13. Stress relaxation curves of Polyesterimide (EI) at various temperatures of Ethyl alcohol (1) $10^{\circ} \mathrm{C},(2) 20^{\circ} \mathrm{C},(3) 30^{\circ} \mathrm{C},(4) 40^{\circ} \mathrm{C}$

Table 5. Amount of stress relaxation of Polyamideimide wire at different solvent temperatures

\begin{tabular}{cccccc}
\hline \multirow{2}{*}{$\begin{array}{c}\text { Solvent } \\
\text { temperature } \\
\left({ }^{\circ} \mathrm{C}\right)\end{array}$} & \begin{tabular}{c} 
Ethyl \\
\cline { 5 - 6 }
\end{tabular} & $\begin{array}{c}\text { Stress } \\
\text { relaxation } \\
\left(\mathrm{kg} / \mathrm{mm}^{2}\right)\end{array}$ & $\begin{array}{c}\text { Dielectric } \\
\text { strength } \\
(\mathrm{kV} / 50 \mu)\end{array}$ & $\begin{array}{c}\text { Dimethyl formamide } \\
\begin{array}{c}\text { relaxation } \\
\left(\mathrm{kg} / \mathrm{mm}^{2}\right)\end{array}\end{array}$ & $\begin{array}{c}\text { Dielectric } \\
\text { strength } \\
(\mathrm{kV} / 50 \mu)\end{array}$ \\
\hline 10 & 4.9 & 3.7 & 3.7 & 4.6 \\
20 & 3.8 & 4.2 & 4.8 & 3.5 \\
30 & 5.0 & 3.0 & 5.7 & 2.2 \\
40 & 5.9 & 2.7 & 7.2 & 1.7 \\
\hline
\end{tabular}

1) Enameled wire temperature, $20^{\circ} \mathrm{C}$.

2) Dielectric strength was measured in $\mathrm{Hg}$ at $25^{\circ} \mathrm{C}$.

3) Enameled wire length, $200 \mathrm{~mm}$.
発生させやすい溶剤は $\Delta T_{g}$ が大きい值を示していることが分かる.

\section{$4 \cdot 4$ 応力緩和曲線に及ぼす溶剤温度の効果}

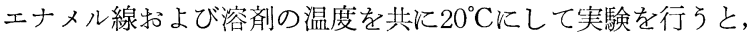

Fig. 2 亿示す二種類の応力緩和曲線が得られた. 次に溶剤の温度 を変えた時の皮膜の応力緩和曲線の举動を検討した．Fig. 12 お

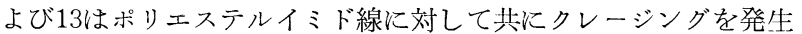
させ，一方は応力緩和を他方は応力增大後応力緩和を示す二つの 溶剤, ジメチルフォルムアミドとメチルアルコールの温度を変え た時の応力緩和曲線を示している. Table 5 はこれらの応力緩和 曲線から得られた応力緩和量とクレージング発生後の皮膜の絶縁 耐力を示している. Fig. 12 抢よび13から分かるよ5に溶剤の温

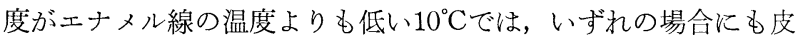
膜は収縮によって応力が増大している。クレージングの発生は一 般的には溶剤温度の上年と共に激しくなる傾向を示す。

\section{5. 結 論}

(1)導体と皮膜との接着の悪いエナメル線を伸長し，各種の溶剤を 塗布すると皮膜の応力が緩和する。この場合，応力緩和曲線は 二つに分類することができる，一つは通常の応力緩和曲線であ り, 他の一つは応力増大後応力緩和を示す曲線である。クレー ジングの発生はいずれの場合にも発生する場合としない場合が ある。

(2)各種エナメル線と各種溶剤を組合せて得られた応力緩和曲線か ら判断すると，これらの応力緩和曲線の形はエナメル線の皮膜 によるのでなく, 溶剤の種類によって決定される，乙かし，応 力緩和量やクレージング発生の有無はエナメル線皮膜と溶剤の 個々の組又合わせはよって異なっている.

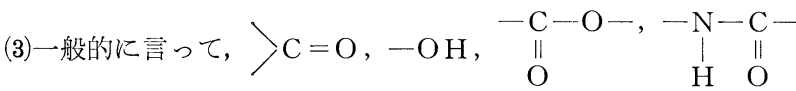
等の極性基をもち誘電定数の高い溶剤は, エナメル線の皮膜に クレージングを発生させやすい傾向をもっている。しかし，誘 電定数だけでクレージングの発生を推定することは困難である。

(4)エナメル線を溶剤に一定期間浸漬した後, 皮膜の $\tan \delta$ 温度特 性曲線が浸漬前の皮膜の $\tan \delta$ 温度特性曲線に比較して大きく 異なるものほど，すなわち皮膜のガラス転移温度を低下させる 能力の大きい溶剤ほどクレージングを発生させやすい傾向をむ っている.

\section{文献}

1）增田重雄, 浅野信之, 田中敏彦, 糸賀輝雄, 日本レオロジー 学会誌，3， 2, 71 (1975).

2) Masuda S., N. Asano, J. Appl. Polym. Sci., 20, 357 (1976).

3) Miller G.W., S.A.D. Visser, and A.S. Morecroft, Polym. Eng. Sci., 11, 2, 73 (1971).

4) Kambour R.P., and R.E. Robertson, General Electric Co. R and D Center, Report No. 70-C-104 (1970).

5) Decoste J.B., F.S. Malm, and V.T. Wallder, Ind. Eng. Chem., 43, 1, 117. 